\title{
Anticoagulants on yield of bone marrow-derived mononuclear cells harvested from dogs
}

\author{
Anticoagulantes no rendimento de células mononucleares da medula óssea de cães \\ Harald Fernando Vicente de Brito $^{I^{*}}$ Tobias Fernandes-Filho ${ }^{I I}$ Fernanda de Lima Brandão $^{\text {III }}$
Patrícia Yukiko Montaño ${ }^{I}$ Luciane Maria Laskoski ${ }^{I}$ Rosangela Locatelli-Dittrich ${ }^{\mathrm{I}}$
}

\section{ABSTRACT}

Cell therapy with bone marrow-derived mononuclear cells is an alternative to therapy with mesenchymal stem cell cultures. The aim of the present research was the comparison of the yield of bone marrow-derived mononuclear cells harvested from dogs with two different anticoagulants. Bone marrow was harvested from the iliac crest of five healthy dogs aged between 15 and 30 months, and the effect of two anticoagulant solutions, CPDA-1 (citrate phosphate dextrose adenine-1) and heparin, on the isolation of mononuclear cells was compared. Mononuclear cells were isolated in a density gradient and stained for CD9 and CD44 for characterization by flow cytometry. Means were compared using Student's paired t-test. Samples harvested with $C P D A-1$ yielded an average of $5.16 \times 10^{6}\left( \pm 1.76 \times 10^{6}\right)$ to $20.20 \times 10^{6}$ $\left( \pm 1.55 \times 10^{6}\right)$ mononuclear cells $/ \mathrm{mL}$, whereas the yield of samples harvested with heparin varied between $4.56 \times 10^{6}\left( \pm 0.69 \times 10^{6}\right)$ and $24.30 \times 10^{6}\left( \pm 2.12 \times 10^{6}\right)$ mononuclear cells $\mathrm{mL}^{-1}$. By flow cytometry, mean percentage of double-stained cells varied from $1.96 \%( \pm 0.64 \%)$ to $5.01 \%( \pm 0.73 \%)$ for $C P D A-1$ and from $2.23 \%$ $( \pm 0.70 \%)$ to $7.27 \%( \pm 0.97 \%)$ for heparin. No significant statistical differences were observed on yield or CD9 and CD44 expression. Further studies are recommended to assess efficacy of CPDA on mononuclear cell isolation.

Key words: mesenchymal stem cells, multipotent stem cell, immunophenotyping.

\section{RESUMO}

A terapia com células mononucleares de medula óssea é uma alternativa ao cultivo de células-tronco mesenquimais. O objetivo deste trabalho foi comparar o rendimento de células mononucleares derivadas da medula óssea de cães, colhidas com dois anticoagulantes diferentes. Foram coletadas medulas ósseas de cinco cães hígidos, com idades variando entre 15 e 30 meses, por punção na crista ilíaca. Foi comparado o efeito da solução anticoagulante no isolamento das células mononucleares, utilizando-se CPDA-1 (citrato, fosfato, dextrose, adenina) ou heparina como soluções anticoagulantes. As células mononucleares foram isoladas em gradiente de densidade e caracterizadas fenotipicamente em citometria de fluxo. Os resultados foram submetidos ao Teste t pareado para comparação de médias. Nas amostras coletadas com CPDA-1, o rendimento

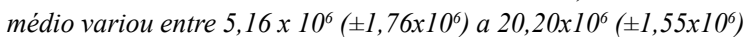
células mononucleares $m L^{-1}$, enquanto que, nas amostras coletadas com heparina, o rendimento variou entre $4,56 \times 10^{6}\left( \pm 0,69 \times 10^{6}\right)$ a $24,30 \times 10^{6}\left( \pm 2,12 \times 10^{6}\right)$ células mononucleares $/ m L$. Na citometria de fluxo, a média de células duplo-marcadas variou de $1,96 \%$

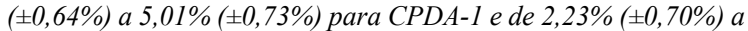
$7,27 \%$ ( $\pm 0,97 \%)$ para heparina. Não foram observadas diferenças estatísticas no rendimento ou na expressão de CD9 e CD44. Recomendam-se estudos adicionais para avaliar melhor a eficácia do CPDA no isolamento de células mononucleares.

Palavras-chave: célula-tronco mesenquimal, célula-tronco multipotente, imunofenotipagem.

\section{INTRODUCTION}

In animals, stem cell therapy is being studied as a treatment option for inflammatory lesions and is generally performed by administration of autologous adipose-derived mesenchymal cells (BLACK et al., 2007). In addition to their structural contribution to tissue repair, mesenchymal stem cells (MSCs) have potent immunomodulatory and anti-inflammatory effects, acting on tissue repair by means of local environment modulation, endogenous progenitor cell

ISetor de Ciências Agrárias, Programa de Pós-graduação em Ciências Veterinárias, Universidade Federal do Paraná (UFPR), Rua dos Funcionários, Juvevê, 1540, 80035-050, Curitiba, PR, Brasil. E-mail:haraldbrito@me.com. "Corresponding Author.

IImunova Análises Biológicas, UFPR, Curitiba, PR, Brasil.

IIIDepartamento de Medicina Veterinária, UFPR, Curitiba, PR, Brasil. 
activation, direct cell-to-cell interaction and secretion of several factors (CHEN \& TUAN, 2008).

MSCs can be isolated from bone marrow, adipose tissue or umbilical cord blood (KERN et al., 2006). Adult stem cells can be isolated from bone marrow and culture-expanded for therapeutic application (JIANG at al., 2004) or used in cell therapy without prior expansion (SOARES et al., 2004). However, stem cells isolated and expanded under different culture conditions differ in their properties and, most likely, in their therapeutic potential (PROCKOP, 2009).

Heparin and CPDA-1 are commonly used to harvest bone marrow (BAUMERT et al., 2008). Heparin is a potent anticoagulant that has effects only in the presence of a plasma component termed heparincofactor (ROSENBERG, 1974), while the CPDA-1 is an adenine-containing preservative solution used to anticoagulant blood over a wider range (BEUTLER $\&$ WEST, 1979). Comparing the effect of in vitro anticoagulants on the viability of lynphocytes, KLEIN et al. (1991) showed that CPDA is better than heparin as regards the protection of lymphocytes. However, the comparison of anticoagulant effects at harvest on terms of stem cell yield has not been studied.

Adult bone marrow-derived stem cells can be obtained by density gradient centrifugation (SOARES et al., 2004). Therefore, the total bone marrow-derived mononuclear cell fraction offers a low-cost alternative to MSC culture (BRITO et al., 2010). Although there are some reports on the use of non-cultured cells for therapy (SOARES et al., 2004; BRITO et al., 2010), most studies use cultureexpanded cells (JUNG et al., 2009; QUIMBY et al., 2011). Despite KAMISHINA et al. (2008) estimated the frequency of canine BMSCs to be 0.0042 $( \pm 0.0019 \%)$. These researchers observed a great variability among bone marrow samples.

Phenotypic characterization of canine bone marrow-derived MSCs expanded has been demonstrated (JUNG et al., 2008; SCREVEN et al., 2014). However, the phenotype of non-cultured canine bone marrow-derived multipotent cells is yet unknown (JIANG at al., 2004).

According to GIMBLE et al. (2007), the phenotypic expression profile changes during culture as a function of time in passage and adherence to plastic. The cited authors' further state that, despite differences in isolation and culture procedures, immunophenotyping is relatively consistent among laboratories.

Stem cell cultures are heterogeneous, comprising different subsets (clones). Clones are also heterogeneous and contain mutations that accumulate during expansion and thus can acquire secondary mutations that may cause cancerous transformations after transplantation. For this reason, the mutation rate of a stem cell lineage, evaluated by gene sequencing, is an important criterion for evaluating the adequacy of such lineages in medical practice (SVERDLOV \& MINEEV, 2013). However, this type of evaluation makes cell therapy highly expensive.

The objective of the present study was the comparison of the yield of bone marrow-derived mononuclear cells harvested from dogs with two different anticoagulants as well as evaluates the difference in the phenotype of the isolated cells for future use of non-expanded cells in cell therapy.

\section{MATERIAL AND METHODS}

Five healthy mixed-breed dogs aged between 15 and 30 months were used for the present study. Bone marrow was harvested from animals under general anesthesia by puncturing the iliac crest with disposable hypodermal needles (16 G) and disposable $10-\mathrm{mL}$ syringes. Two $8-\mathrm{mL}$ samples of marrow bonewere withdrawn from each dog, one containing 2.0mL CPDA-1 (citrate phosphate dextrose adenine-1) anticoagulant solution and the other $2.0 \mathrm{~mL}$ anticoagulant solution composed of $1.0 \mathrm{~mL}$ heparin $(5000 \mathrm{IU} / \mathrm{mL})$ and $1.0 \mathrm{~mL}$ phosphate buffered saline (PBS). All samples were diluted with $10 \mathrm{~mL}$ Dulbecco's Modified Eagle Medium (DMEM, Sigma ${ }^{\circledR}$ ). For density gradient isolation, six 15-mL Falcon tubes were prepared containing a bottom layer of $1.5 \mathrm{~mL}$ Histopaque $1119\left(\right.$ Sigma $\left.^{\circledR}\right)$ and $1.5 \mathrm{~mL}$ Histopaque 1077 $\left(\right.$ Sigma $\left.^{\circledR}\right)$ carefully layered on top. Samples were divided into six homogenous 3-mL aliquots and layered onto the Histopaque solutions by means of gravity sedimentation. Tubes were centrifuged at $950 \mathrm{~g}$ for $30 \mathrm{~min}$. After centrifugation, the layer of mononuclear cells was collected with a serological pipette and washed twice with 5.0mL DMEM by centrifugation at $400 \mathrm{~g}$ for $10 \mathrm{~min}$. After washing, cells were resuspended in PBS and evaluated in a hematology analyzer (BC2800Vet, Mindray).

For phenotypic assay of mononuclear cells the antibodies were used according to a previous report for characterization of canine mesenchymal stem cells (JUNG et al., 2008). Homologous control was used as negative control. A total of $1.0 \times 10^{6}$ cells from each sample were resuspended in $10 \mu \mathrm{L}$ PBS containing $1.0 \mu \mathrm{L}$ Anti-Human-CD9 (conjugated to R. Phyoerythrin) (AbDserotec; IgG concentration 
$1.0 \mathrm{mg} \mathrm{mL}^{-1}$ ) and $1.0 \mu \mathrm{L}$ Anti-Dog-CD44 (conjugated to FITC) antibodies (AbDserotec; IgG concentration $0.05 \mathrm{mg} \mathrm{mL}^{-1}$ ) and incubated for $40 \mathrm{~min}$. Cells were subsequently resuspended in $400 \mu \mathrm{L}$ PBS and analyzed by flow cytometry (FACSCalibur, BD).

Results for the number of obtained cells $\mathrm{mL}^{-1}$ of bone marrow and the percentage of stained cells in immunophenotyping were submitted to statistical analysis using Student's paired $t$-test for the comparison of means.

\section{RESULTS}

The mean yield of mononuclear cells was similar in all samples $(\mathrm{P}>0.05)$ with regard to the anticoagulants used at harvest, i.e., CPDA-1 or heparin (Table 1). Specifically, samples harvested with CPDA-1 yielded an average of $5.16 \times 10^{6}$ $\left( \pm 1.76 \times 10^{6}\right)$ to $20.20 \times 10^{6}\left( \pm 1.55 \times 10^{6}\right)$ mononuclear cells $/ \mathrm{mL}$, whereas samples harvested with heparin yielded between $4.56 \times 10^{6}\left( \pm 0.69 \times 10^{6}\right)$ and $24.30 \times 10^{6}$ $\left( \pm 2.12 \times 10^{6}\right)$ mononuclear cells $\mathrm{mL}^{-1}$.

By flow cytometry, the mean percentage of CD9-stained cells varied between $0.07 \%$ $( \pm 0.03 \%)$ and $1.38 \%( \pm 0.40 \%)$ of the total cells in samples harvested with CPDA- 1 and between $0.17 \%$ $( \pm 0.10 \%)$ and $1.16 \%( \pm 0.15 \%)$ in samples harvested with heparin. For CD44-staining the variation was between $43.05 \%( \pm 4.14 \%)$ and $73.58 \%( \pm 5.03 \%)$ for samples harvested with CPDA-1 and between $43.87 \%( \pm 2.39 \%)$ and $69.67 \%( \pm 7.64 \%)$ for samples harvested with heparin. The mean percentage of double-stained cells (Table 2) varied between $1.96 \%$ $( \pm 0.64 \%)$ and $5.01 \%( \pm 0.73 \%)$ for samples harvested with CPDA-1 and between $2.23 \% \quad( \pm 0.70 \%)$ and $7.27 \%( \pm 0.97 \%)$ for samples harvested with heparin. However, the observed differences were not statistically significant $(\mathrm{P}>0.05)$.

\section{DISCUSSION}

In the present study, mononuclear cells were isolated according to a previous report (SOARES et al., 2004), and has been compared the yield of bone marrow-derived mononuclear cells harvested from dogs with two different anticoagulants as well as assessed the difference in the phenotype of the isolated cells.

Although KLEIN et al. (1991) emphasizes the importance of choosing the right anticoagulant when there is viability of lymphocytes, in this study no differences were observed on the viability of cells obtained with CPDA or heparin.

In study focusing on the influence of different anticoagulants on chemotactic reactivity, the heparin has been considered the most suitable and safe anticoagulant for freshly isolated bone marrow hematopoietic stem and progenitor cells (BAUMERT et al., 2008). In this study, we have not found significant differences at harvest in terms of stem cell yield with both anticoagulants tested.

ABBIT \& NASH (2001) compared the effect of anticoagulants in the characteristics of leucocyte adhesion and showed that whereas nearly all-adherent leucocytes were rolling with CDPA, a large proportion were stationary adherent with heparin. However, the authors found no significant differences in CD11b on neutrophils expression during storage.

In the present research it was compared the concomitant expression of CD9 and CD44 by flow cytometry. Staining for CD9 was obtained in less than $2 \%$ and for CD44 in approximately $70 \%$ of the isolated cells regardless of the anticoagulant used for bone marrow harvest. The percentage of staining for CD44, a characteristic marker for bone marrow-derived mesenchymal cells (KOCHER et al.,

Table 1 - Comparison of two anticoagulants (CPDA-1 and heparin) used for the harvest of canine bone marrow in terms of mean yield of cells and standard deviation (SD).

\begin{tabular}{|c|c|c|c|c|}
\hline \multirow{2}{*}{ Animal } & \multicolumn{4}{|c|}{ 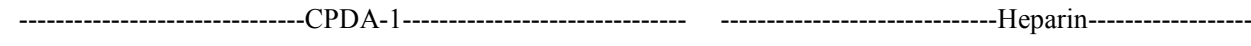 } \\
\hline & Mean & $\mathrm{SD}$ & Mean & $\mathrm{SD}$ \\
\hline 1 & $20.20 \times 10^{6}$ & $1.55 \times 10^{6}$ & $24.30 \times 10^{6}$ & $2.12 \times 10^{6}$ \\
\hline 2 & $9.89 \times 10^{6}$ & $4.36 \times 10^{6}$ & $4.56 \times 10^{6}$ & $0.69 \times 10^{6}$ \\
\hline 3 & $13.60 \times 10^{6}$ & $1.28 \times 10^{6}$ & $7.94 \times 10^{6}$ & $1.06 \times 10^{6}$ \\
\hline 4 & $10.70 \times 10^{6}$ & $3.63 \times 10^{6}$ & $4.89 \times 10^{6}$ & $1.09 \times 10^{6}$ \\
\hline 5 & $5.16 \times 10^{6}$ & $1.73 \times 10^{6}$ & $16.20 \times 10^{6}$ & $2.14 \times 10^{6}$ \\
\hline
\end{tabular}

The observed differences were not statistically significant $(\mathrm{P}>0.05)$.

CPDA-1: citrate phosphate dextrose adenine-1.

Ciência Rural, v.45, n.11, nov, 2015. 
Table 2 - Mean percentage and standard deviation (SD) in cells isolated from canine bone marrow double-stained (CD9 and CD44).

\begin{tabular}{lcccc}
\hline \multirow{2}{*}{ Animal } & \multicolumn{2}{c}{ Double-stained cells with CPDA-1 } & \multicolumn{2}{c}{ Double-stained cells with Heparin } \\
& mean & SD & mean & 0.70 \\
1 & 5.01 & 0.73 & 2.23 & 0.66 \\
2 & 3.20 & 1.84 & 3.73 & 5.96 \\
5 & 4.88 & 1.01 & 7.27 & 0.97 \\
5 & 1.96 & 0.64 & 5.78 & 2.10 \\
\hline
\end{tabular}

The observed differences were not statistically significant $(\mathrm{P}>0.05)$. CPDA-1: citrate phosphate dextrose adenine-1.

2001), observed in the present study was equivalent to that reported by SCREVEN et al. (2014), who demonstrated staining for CD44 in $65.1 \%$ of canine adipose-derived mesenchymal cells. However, the authors showed only $20-30 \%$ of the bone marrowderived MSCs were stained positive for CD44. The CD44, or H-CAM, is a multifunctional cell adhesion molecule (ROA et al., 2001) that was first identified as a lymphocyte-homing receptor and is highly expressed in antigen-activated $\mathrm{T}$ cells and in $\mathrm{T}$ cells with transendothelial migratory capacity. In peripheral blood, most $\mathrm{CD}^{+}$cells have a CD44 low phenotype (BRENNAN et al., 1999). H-CAM functions include cell-cell and cell-substrate adhesion (LEWINSOHN et al., 1990), as well as lymphocyte homing, hematopoiesis, angiogenesis, cytokine release and hyaluronic acid metabolism and degradation (ROA et al., 2001).

The CD9 antigen is a transmembrane protein of the tetraspanin superfamily (KLEINSOYER et al., 2000). In the hematopoietic system, CD9 is expressed in young B cells, platelets, eosinophils, basophils and activated T lymphocytes (BOUCHEIX et al., 1991; ANTON et al., 1995). CD9 is not expressed by hematopoietic progenitors or nonactivated lymphocytes (BOUCHEIX et al., 1991). In $B$ cells and platelets, CD9 regulates cell activation and aggregation, possibly by association with an integrin. In other cells, CD9 regulates cell motility (ANTON et al., 1995). CD9 has also been reported in cells of the central and peripheral nervous system (MEISTER at al., 2007). MARTIN et al. (2002) have obtained approximately 92\% CD9-stained cells in second- and third-passage cultures of bone marrow-derived cells harvested from cats.

Although KERN et al. (2006) have reported strong expression of CD90 in adult human bone marrow-derived stem cells, studies with bone marrow and adipose-derived canine mesenchymal stem cells (TAKEMITSU et al., 2012) and with canine umbilical cord blood- derived mesenchymal stem cells (SEO et al., 2009) have showed low expression of this marker. TAKEMITSU et al. (2012) and SEO et al. (2009) also reported low expression of CD73, however this marker is not commercially available.

Concomitant CD9 and CD44 staining has been reported for MSC phenotyping in dogs (JUNG et al., 2009) and cats (MARTIN et al., 2002). However, there are no studies showing the phenotypic characterization of non-cultured cells harvested from dogs. According to GIMBLE et al. (2007) immunophenotyping is relatively consistent among laboratories despite the differences in isolation and culture procedures.

The reported frequency of MSCs in canine bone marrow was estimated to be 0.0042 $( \pm 0.0019 \%)$ of mononuclear cells as demonstrated in studies on colony-forming-unit fibroblasts (CFU-F) (KAMISHINA et al., 2008). Interestingly, CD9 and CD44 staining concomitantly, which characterizes mesenchymal cells, was obtained for $1.96 \%$ to $7.27 \%$ of mononuclear cells in the present study. Considering that phenotyping is generally performed on cultured cells after the first passage (JIANG at al., 2004; JUNG et al., 2009; MARTIN et al., 2002; SCREVEN et al., 2014), the differences in double-staining and the frequency reported in studies on CFU-F may be due to the loss of non-adherent mesenchymal cells.

\section{CONCLUSION}

The results of the present study indicate promising possibilities to use of CPDA-1 to harvest bone marrow with the aim to isolate mononuclear cells. Further studies are needed to evaluate the influence of CPDA-1 on expanded cells and in the expression on non-expanded cells of several additional surface markers. 


\section{BIOETHICS AND BIOSSECURITY COMMITTEE APPROVAL}

This study protocol was approved by the Animal Use Ethics Committee of the Agricultural Sciences Department of the Universidade Federal do Paraná, Southern Brazil (CEUA-SCA/ UFPR number 030/2011).

\section{ACKNOWLEDGEMENTS}

The present study was developed with the support of veterinarians from the Veterinary Hospital of Universidade Federal do Paraná (UFPR). We would also like to thank Prof. Dr. Luiz Felipe Caron, who provided the facilities of his laboratory, the dog owners, who brought their animals for bone marrow harvest and, to Coordenação de Aperfeiçoamento de Pessoal de Nível Superior (CAPES) for scholarship to the first author.

\section{REFERENCES}

ABBITT, K.B.; NASH, G.B. Characteristics of leucocyte adhesion directly observed in flowing whole blood in vitro. British Journal of Hematology, v.112, p.55-63, 2001. Available from: <http:// onlinelibrary.wiley.com/doi/10.1046/j.1365-2141.2001.02544.x/ full>. Accessed: Ago. 26, 2014. doi: 10.1046/j.13652141.2001.02544.x

ANTON, E.S. et al. CD9 plays a role in Schwann cell migration in vitro. Journal of Neuroscience, v.15, p.584-595, 1995. Available from: <http://www.jneurosci.org/content/15/1/584.full.pdf + html $>$. Accessed: Jul. 29, 2013. doi: 0270-6474/95/150584-12

BAUMERT, B. et al. An optimization of hematopoietic stem and progenitor cell isolation for scientific and clinical purposes by the application of a new parameter determining the hematopoietic graft efficacy. Folia Histochemica et Cytobiologica, v.46, p.299305, 2008. Available from: $<$ http://czasopisma.viamedica.pl/fhc/ article/view/4414/3669>. Accessed: Aug. 13, 2014. doi: 10.2478/ v10042-008-0045-0.

BEUTLER, E.; WEST, C. The storage of hard-packed red blood cells in citrate- phosphate-dextrose (CPD) and CPD-adenine (CPDA-1). Blood, v.54, p.280-284, 1979. Available from: $<$ http:// www.bloodjournal.org/content $/ 54 / 1 / 280$ ?sso-checked $=$ true $>$. Accessed: Jul. 5, 2014

BLACK, L.L. et al. Effect of adipose-derived mesenchyma stem and regenerative cells on lameness in dogs with chronic osteoarthritis of the coxofemoral joints: a randomized, doubleblinded, multicenter controlled trial. Veterinary Therapeutics v.8, p.272, 2007. Available from: <http://www.celltrovet.com.br/ publicacoes/03.pdf>. Accessed: Aug. 2, 2012

BOUCHEIX, C. et al. Molecular cloning of the CD9 antigen. A new family of cell surface proteins. Journal of Biological Chemistry, v.266, p.117-122, 1991. Available from: <http:// www.jbc.org/content/266/1/117.full.pdf + html>. Accessed: Jul. $29,2013$.

BRENNAN, F.R. et al. CD44 is involved in selective leucocyte extravasation during inflammatory central nervous system disease. Immunology, v.98, p.427-435, 1999. Available from: <http:/ www.ncbi.nlm.nih.gov/pmc/articles/PMC2326932/>. Accessed Jul. 8, 2013. doi: 10.1046/j.1365-2567.1999.00894.x.
BRITO, H.F.V. et al. Tratamento de sequelas neurológicas em cães, causadas por infecção pelo vírus da cinomose através do transplante alogênico de células mononucleares de medula óssea. Medvep - Revista Científica de Medicina Veterinária Pequenos Animais e Animais de Estimação, v.8, p.26-29, 2010.

CHEN, F.H.; TUAN, R.S. Mesenchymal stem cells in arthritic diseases. Arthritis Research \& Therapy, v.10, p.223, 2008. Available from: <http://stem-cell-bank.tran-scell.com/journals/3. pdf $>$. Accessed: Jul. 8, 2013. doi: 10.1186/ar2514.

GIMBLE, J.M. et al. Adipose-derived stem cells for regenerative medicine. Circulation Research, v.100, p.12491260, 2007. Available from: <http://circres.ahajournals.org/ content/100/9/1249.full>. Accessed: Aug. 1, 2013. doi: 10.1161/01. res.0000265074.83288.09.

JIANG, Y. et al. Pluripotency of mesenchymal stem cells derived from adult marrow. Nature, v.418, p.41-49, 2002. Available from: <http:/www.nature.com/nature/journal/v418/n6893/abs/ nature00870.html>. Accessed: Jul. 25, 2013. doi: 10.1038/ nature 00870 .

JUNG, D.I. et al. Canine mesenchymal stem cells derived from bone marrow: isolation, characterization, multidiferentiation, and neurotrophic factor expression in vitro. Journal of Veterinary Clinics, v.25, p.457-464, 2008. Available from: <http://www.dbpia. co.kr/Journal/ArticleDetail/2430048>. Accessed: Jun. 8, 2012.

JUNG, D.I. et al. A comparison of autologous and allogenic bone marrow-derived mesenchymal stem cell transplantation in canine spinal cord injury. Journal of the Neurological Sciences, v.285, p.67-77, 2009. Available from: <http://www.sciencedirect.com/ science/article/pii/S0022510X09006315>. Accessed: Oct. 8, 2012. doi: 10.1016/j.jns. 2009.05.027.

KAMISHINA, $\mathrm{H}$. et al. The frequency, growth kinetics, and osteogenic/adipogenic differentiation properties of canine bone marrow stromal cells. In Vitro Cellular \& Developmental Biology - Animal, v.44, p.472-479, 2008. Available from: $<$ http://www.bioone.org/doi/abs/10.1007/s11626-008-9137-6>. Accessed: Jan. 16, 2015. doi: 10.1007/s 11626-008-9137-6.

KERN, S. et al. Comparative analysis of mesenchymal stem cells from bone marrow, umbilical cord blood, or adipose tissue. Stem Cells, v.24, p.1294-1301, 2006. Available from: <http:// onlinelibrary.wiley.com/doi/10.1634/stemcells.2005-0342/full>. Accessed: May 7, 2013. doi: 10.1634/stemcells.2005-0342.

KLEIN, A. et al. Effect of anticoagulants in vitro on the viability of lymphocytes and content of free fatty acids in plasma. In vitro cellular and developmental biology, v.27, p.307-311, 1991. Available from: <http://link.springer.com/article/10.1007\%2FB F02630908?LI=true $>$. Accessed: Oct. 10, 2014. doi: 10.1007/ BF02630908.

KLEIN-SOYER, C. et al. CD9 participates in endothelial cell migration during in vitro wound repair. Arteriosclerosis, Thrombosis, and Vascular Biology, v.20, p.360-369, 2000. Available from: <http://atvb.ahajournals.org/content/20/2/360. full>. Accessed: Jul. 29, 2013. doi: 10.1161/01.ATV.20.2.360.

KOCHER, A. et al. Neovascularization of ischemic myocardium by human bone-marrow-derived angioblasts prevents cardiomyocyte apoptosis, reduces remodeling and improves cardiac function. Nature Medicine, v.7, p.430-436, 2001. Available from: <http:// 
www.nature.com/nm/journal/v7/n4/abs/nm0401_430.html $>$. Accessed: Jul. 24, 2013. doi: 10.1038/86498.

LEWINSOHN, D. et al. Hematopoietic progenitor cell expression of the H-CAM (CD44) homing- associated adhesion molecule. Blood, v.75, p.589-595, 1990. Available from: <http://www.ncbi. nlm.nih.gov/pubmed/1688719>. Accessed: Sept. 2, 2011.

MARTIN, D.R. et al. Isolation and characterization of multipotential mesenchymal stem cells from feline bone marrow. Experimental Hematology, v.30, p.879-886, 2002. Available from: <http:// www.sciencedirect.com/science/article/pii/S0301472X02008640>. Accessed: Jul. 16, 2012. doi: 10.1016/S0301-472X(02)00864-0.

MEISTER, R.K. et al. Progress in the discovery and definition of monoclonal antibodies for use in feline research. Veterinary Immunology and Immunopathology, v.119, p.38-46, 2007. Available from: $<$ http://www.sciencedirect.com/science/article/pii/ S0165242707002139>. Accessed: Jul. 08, 2013. doi: 10.1016/j. vetimm.2007.06.012.

PROCKOP, D.J. Repair of tissues by adult stem/progenitor cells (MSCs): controversies, myths, and changing paradigms. Molecular Therapy, v.17, p.939-946, 2009. Available from: $<$ http://www.nature.com/mt/journal/v17/n6/full/mt200962a. html>. Accessed: Jun. 08, 2011. doi: 10.1038/mt.2009.62.

QUIMBY, J.M. et al. Evaluation of intrarenal mesenchymal stem cell injection for treatment of chronic kidney disease in cats: a pilot study. Journal of Feline Medicine \& Surgery, v.13, n.6, p.418-426, 2011. Available from: <http://www.sciencedirect. com/science/article/pii/ S1098612X11000234>. Accessed: Feb. 9, 2012. doi: 10.1016/j.jfms.2011.01.005.

ROA, I. et al. Expresión de CD44 (HCAM) en el carcinoma subseroso de la vesícula biliar. Revista Médica de Chile, v.129, p.727-734, 2001. Available from: <http://www.scielo.cl/scielo. php pid $=$ S0034-98872001000700004\&script $=$ sci_arttext $>$. Accessed: Jul. 29. 2013. doi: 10.4067/S0034-98872001000700004.

ROSENBERG, R.D. Heparin action. Circulation, v.49, p.603-605, 1974. Available from: $<$ http://circ.ahajournals.org/content/49/4/603. short>. Accessed: Sep. 2, 2014. doi: 10.1161/01.CIR.49.4.603.

SEO, M-S. et al. Isolation and characterization of canine umbilical cord blood-derived mesenchymal stem cells. Journal of Veterinary Science, v.10, p.181-187, 2009. Available from: $<$ http://europepmc.org/articles/PMC2801133>. Accessed: May 27, 2014. doi: $10.4142 /$ jvs.2009.10.3.181.

SCREVEN, R. et al. Immunophenotype and gene expression profile of mesenchymal stem cells derived from canine adipose tissue and bone marrow. Veterinary Immunology and Immunopathology, v.161, p.21-31, 2014. Available from: <http://www.ncbi.nlm.nih.gov/pubmed/25026887>. Accessed: Jan. 7, 2015. doi: 10.1016/j.vetimm.2014. 06.002.

SOARES, M.B.P. et al. Transplanted bone marrow cells repair heart tissue and reduce myocarditis in chronic chagasic mice. American Journal of Pathology, v.164, p.441-447, 2004. Available from: <http://www.sciencedirect.com/science/article/ pii/S0002944010631343>. Accessed: Jul. 24, 2013. doi: 10.1016/ S0002-9440(10)63134-3.

SVERDLOV, E.D.; MINEEV, K. Mutation rate in stem cells: an underestimated barrier on the way to therapy. Trends in Molecular Medicine, v.19, p.273-280, 2013. Available from: <http://www. sciencedirect.com/science/article/pii/S1471491413000191>. Accessed: Aug. 7, 2013. doi: 10.1016/j.molmed.2013.01.004.

TAKEMITSU, H. et al. Comparison of bone marrow and adipose tissue-derived canine mesenchymal stem cells. BMC Veterinary Research, v.8, p.150, 2012. Available from: <http://www. biomedcentral.com/1746-6148/8/150>. Accessed: May 27, 2014. doi: $10.1186 / 1746-6148-8-150$. 